\title{
PENGARUH KUALITASS PELAYANAN TERHADAP KEPUASAN, NILAI, KEPERCAYAAN DAN LOYALITAS PELANGGAN RUMAH TANGGA PADA PERUSAHAAN DAERAH AIR MINUM KOTA KENDARI
}

Oleh:

\author{
Abdul Kadir ${ }^{1}$, Muhammad Basri' ${ }^{2}$ Rodi $^{3}$ \\ ${ }^{1,2}$ Depatement of Public Administration, Universitas Halu Oleo, Kendari \\ ${ }^{3}$ Mahasiswa Jurusan Ilmu Administrasi Publik Universitas Halu Oleo \\ 'Habdulkadir64@yahoo.com, ’2muhammadbasri275@gmail.com
}

\begin{abstract}
This study aims to determine the effect of service quality on customer loyalty mediated by Customer satisfaction and customer value eddition, it also examines, the effect of service quality on customer satisfaction, which is mediated by the effect of costumer value and customer satisfaction and customer value on customer loyalty mediated by trust. The population in this study are household customers in Kendari who use the services of PDAM for 17,607 households spread are over 10 (ten) districts. The samples in this study are 391 household customers are taken with a precision of $5 \%$ Data Collection techniques utilittes questionare. Data are analized by using. Structural Equation Modelling (SEM) with the help of the program, some of the important findings in this study are : (1) better service improvement of Kendari Regional causes trust, (2) customer loyalty improvement is also achievable of the provided service is able to enhance customer value. Bisides, this research also proves that trust has mediating role between satisfaction and loyalty of are customers as well as between customer value and loyalty.
\end{abstract}

Keywords : service quality, customer satisfaction, customer value, customer trust and customer loyalty.

\section{LATAR BELAKANG}

Perusahaan Daerah Air Minum (PDAM) Kota Kendari adalah Perusahaan Milik Pemerintah Daerah. Dalam operasionalnya sebagai institusi pelayanan masyarakat akan kebutuhan air bersih, PDAM harus dikelola dengan baik berdasarkan asas manfaat ekonomi dan manfaat sosial. Sebagai perusahaan yang menghasilkan produk berupa air bersih, kualitas pelayanan merupakan aspek penting dalam mencapai tujuan Perusahaan. Namun demikian kualitas pelayanan sangat dipengaruhi oleh berbagai aspek layanan terkait dengan kepuasan pelanggan.

Fenomena empirik yang terjadi pada PDAM Kota Kendari adalah pelanggan yang menunggak pembayaran rekening air bersih dariu tahun ke tahun semakin meningkat seperti Tabel 1 berikut :

Tabel 1. Jumlah Pelanggan yang Menunggak Tahun 2006-2010

\begin{tabular}{|l|c|c|c|c|c|}
\hline \multicolumn{1}{|c|}{ Kategori Pelanggan } & 2006 & 2007 & 2008 & 2009 & 2010 \\
\hline Jumlah Pelanggan (Unit) & 15.564 & 15.884 & 16.240 & 17.489 & 18.342 \\
Jumlah Menunggak (Unit) & 3.046 & 3.615 & 3.757 & 4.727 & 4.866 \\
Persentase (\%) & 19,57 & 22,75 & 23,65 & 27,02 & 27,25 \\
\hline
\end{tabular}

Sumber: PDAM Kota Kendari 2011 
Berdasarkan tabel l diatas, menunjukan bahwa dari tahun ketahun jumlah pelanggan yang menunggak pembayaran rekening air bersih semakin meningkat, sehingga mengindikasikan bahwa pelanggan kurang loyal pada perusahaan PDAM Kota Kendari. Hal ini merupakan permasalahan manajerial yang menarik untuk diteliti, yakni apa faktor yang menyebabkan loyalitas pelanggan pada PDAM Kota Kendari semakin menurun. Apakah hal ini didasari oleh adanya ketidakpuasan atas pelayanan yang diterima oleh pelanggan dan jauh dari keinginan, yaitu harapan dan terpenuhinya akan kebutuhan air bersih dan rendahnya kualitas air bersih yang tersedia.

Sebagai perusahaan yang menghasilkan produk berupa air bersih, kualitas layanan yang baik bagi pelanggan Perusahaan Daerah Air Minum (PDAM) merupakan aspek penting dalam mencapai tujuan perusahaan, namun pelayanan yang diberikan karyawan PDAM Kota Kendari terhadap pelanggan selama ini tidak sesuai dengan apa yang diharapkan oleh pelanggan seperti : aspek pengurusan penyambungan yang tidak lancar, biaya yang relatif tinggi, mengalirnya air tidak kuat sampai kesemua pelanggan, sehingga menyebabkan pelanggan menggunakan mesin pompa air sendiri sebagai alat bantu untuk mendorong masuknya air ketempat masingmasing pelanggan tersebut. Kekuatan arus air yang disalurkan oleh PDAM tidak mampu sampai ke pelanggan secara merata, bahkan sebagian pelanggan hanya mendapatkan angin yang keluar dari masing-masing pipa air, walaupun meteran air yang digunakan pelanggan pada saat itu mengalami perputaran yang lebih cepat, yang mengakibatkan pelanggan membayar lebih mahal dari biasanya. Komplain kerusakan meteran dan bocornya pipa saluran air lamban ditangani, jaminan ketersediaan kualitas air bersih sepanjang tahun kurang memadai, serta seringnya kesalahan dalam pencatatan penggunaan meteran air pelanggan. Pelanggan berusaha mencari alternatif sumber air lain yang bisa didapatkan oleh pelanggan, seperti sumur bor yang lebih memungkinkan tersedianya kualitas air lebih jernih, sehingga biaya yang dikeluarkan oleh pelanggan atas ketersediaan air semakin meningkat. Pelanggan sering melakukan penunggakan pembayaran air bersih yang digunakan dari PDAM terutama pelanggan yang memiliki sumur bor atau sumur biasa.

Hubungan antara kualitas layanan dan kepuasan pelanggan. Afsar (2010), membuktikan bahwa ada pengaruh positif dan signifikan variabel kualitas layanan terhadap kepuasan pelanggan. Namun Frimpong, Nwankwo dan Dason (2010), membuktikan bahwa ada pengaruh positif namun tidak signifikan dari variabel kualitas layanan terhadap kepuasan pelanggan. Sementara itu Trivellas (2010) menyatakan bahwa mutu layanan berpengaruh positif dan signifikan terhadap loyalitas pelanggan. Selanjutnya Kasim dan Abdullah (2010) menyatakan disamping kepuasan terhadap loyalitas yang diperkuat dengan Zahara (2007).

Berdasarkan penelitian terdahulu tentang loyalitas pelanggan, dapat disimpulkan adanya upaya untuk memperjelas hubungan antara kualitas pelanggan, kepuasan dan nilai pelanggan, kepercayaan dan loyalitas pelanggan. Namun sampai saat ini masih berkembang bagaimana sebenarnya variabel hubungan antara kualitas layanan terhadap kepuasan, dan loyalitas pelanggan karena hasilnya masih bervariasi. Oleh karena itu, pada penelitian ini peneliti mencoba untuk melihat 2 (dua) variabel lain pada konsep hubungan antara kualitas layanan terhadap loyalitas, yakni menambahkan variabel nilai pelanggan yang memediasi hubungan antara kualitas layanan dan kepuasan pelanggan serta variabel kepercayaan yang memediasi antara variabel kepuasan pelanggan dengan loyalitas pelanggan dan nilai pelanggan dengan loyalitas pelanggan Chung Hao Chen (2009) dan Lai, et al (2008).

\section{RUMUSAN MASALAH}

Berdasarkan penjelasan diatas, menjadikan peneliti tertarik untuk meneliti kembali variabel-variabel anteseden dari loyalitas pelanggan yang selama ini telah dilakukan, namun masih terdapat perbedaan hasil dari hubungan variabel tersebut dengan cara melihat secara keseluruhan variabel-variabel yang digunakan oleh penelitipeneliti terdahulu. Di samping itu, peneliti ingin melihat lebih jauh model hubungan langsung dan tidak langsung diantara variabel-variabel anteseden dari loyalitas tersebut. 


\section{METODE PENELITIAN}

Rancangan penelitian yang digunakan adalah confirmatory research dengan menggunakan metode nonexperimental dan data cross section. Penelitian conformatory dengan menggunakan metode nonexperimental adalah merupakan bentuk penelitian yang bertujuan untuk memperoleh pengujian yang tepat dan menarik kesimpulan hubungan sebab akibat antar variabel penelitian dan selanjutnya memilih alternatif tindakan (Kuncoro, 2003 : 75). Alasan yang mendasari digunakan confirmatory research adalah karena penelitian ini bertujuan untuk menguji dan menganalisis pengaruh langsung kualitas layanan, nilai pelanggan, kepuasan pelanggan, kepercayaan pelanggan terhadap loyalitas pelanggan, disamping itu untuk menganalisis pengaruh kualitas layanan terhadap loyalitas pelanggan melalui kepuasan, nilai dan kepercayaan pelanggan. Di samping menggunakan pendekatan kuantitatif, penelitian ini juga menggunakan pendekatan kualitatif untuk memperdalam hasil dari kuantitatif. Popupasi dalam penelitian ini adalah pelanggan rumah tangga yang berdomisili di Kota Kendari yang menggunakan jasa PDAM berjumlah 17.607 rumah tangga yang tesebar di 10 (sepuluh) Kecamatan. Penarikan sampel menggunakan metode Propotional Random Sampling. Metode analisis data menggunakan metode teknik Structural Equation Model (SEM). Proses analisis data didahului dengan analisis deskriptif yang digunakan untuk melengkapi deskripsi fakta empirik dari model konseptual yang telah diuji hipotesisnya dan untuk mendiskripsikan logika manajemen atas berbagai proses yang tersirat dalam hipotesis yang diuji serta dimaksudkan untuk mengetahui distribusi frekuensi jawaban dari hasil kuisioner (Ferdinand, 2002) dan selanjutnya dilakukan pengujian hipotesis dan menginterpretasi hasil yang diperoleh.

\section{HASIL PENELITIAN DAN PEMBAHASAN}

Pada penelitian ini, melibatkan 5 (lima) variabel yaitu : Kualitas Pelayanan, Kepuasan, Nilai, Kepercayaan dan Loyalitas Pelanggan Rumah Tangga terhadap Perusahaan Daerah Air Minum (PDAM) Kota Kendari. Berikut ini akan dijelaskan melalui tabel hasil pengujian hipotesis sebagaimana Tabel 2.

Tabel 2. Model Struktural Hasil SEM

\begin{tabular}{|lll|c|c|c|}
\hline \multicolumn{2}{|c|}{ Hubungan Antar Variabel } & Koefisien & P-Value & Keterangan \\
\hline Kualitas Layanan & $\longrightarrow$ & Kepuasan Pelanggan & 0.173 & 0.021 & Signifikan \\
Kualitas Layanan & $\longrightarrow$ & Nilai Pelanggan & 0.179 & 0.014 & Signifikan \\
Nilai Pelanggan & $\longrightarrow$ & Kepuasan Pelanggan & 0.191 & 0.010 & Signifikan \\
Kepuasan Pelanggan & $\longrightarrow$ & Kepercayaan Pelanggan & 0.164 & 0.028 & Signifikan \\
Nilai Pelanggan & $\longrightarrow$ & Kepercayaan Pelanggan & 0.174 & 0.018 & Signifikan \\
Kepuasan Pelanggan & $\longrightarrow$ & Loyalitas Pelanggan & 0.077 & 0.303 & Tidak Signifikan \\
Nilai Pelanggan & $\longrightarrow$ & Loyalitas Pelanggan & 0.162 & 0.033 & Signifikan \\
Kepercayaan Pelanggan & $\longrightarrow$ & Loyalitas Pelanggan & 0.190 & 0.013 & Signifikan \\
\hline
\end{tabular}

Sumber : Data Primer Diolah 2012

Hasil pengujian model struktural diatas, dapat disajikan pada diagram dibawah ini sebagaimana Gambar 1. 


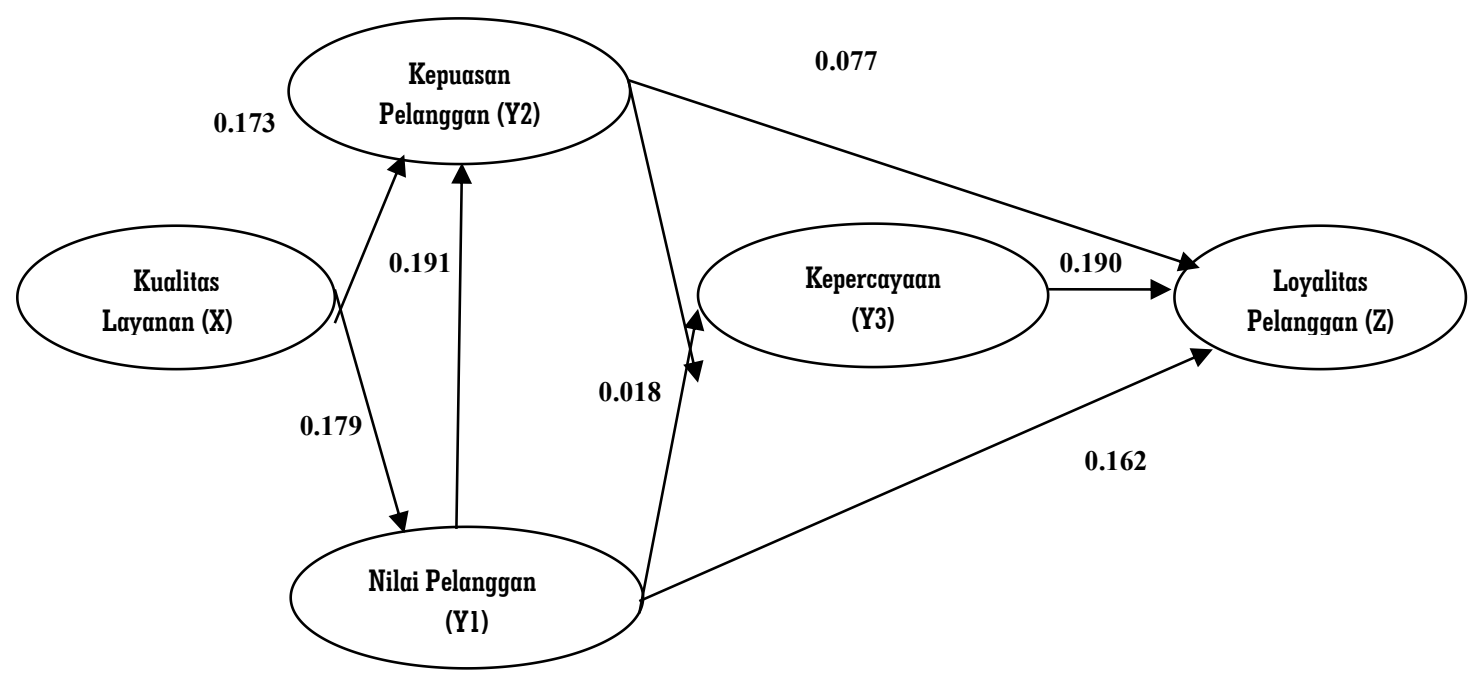

Gambar 1. Hasil Structural Equation Model (SEM)

Berdasarkan Tabel 2 dan Gambar 1, maka hasil pengujian model struktural yang disajikan sebagai berikut :

1. Terdapat pengaruh yang signifikan dan positif antara Kualitas Layanan terhadap Kepuasan Pelanggan. Artinya semakin tinggi Nilai Kualitas Layanan, semakin tinggi pula Nilai Kepuasan Pelanggan.

2. Terdapat pengaruh yang signifikan dan positif antara Kualitas Layanan terhadap Nilai Pelanggan. Artinya semakin tinggi Nilai Kualitas Layanan, semakin tinggi pula Nilai Pelanggan.

3. Terdapat pengaruh yang signifikan dan positif antara Nilai Pelanggan terhadap Kepuasan Pelanggan. Artinya semakin tinggi Nilai Pelanggan, semakin tinggi pula Kepuasan Pelanggan.

4. Terdapat pengaruh yang signifikan dan positif antara Kepuasan Pelanggan terhadap Kepercayaan Pelanggan. Artinya semakin tinggi Kepuasan Pelanggan, semakin tinggi pula Kepercayaan Pelanggan.

5. Terdapat pengaruh yang signifikan dan positif antara Nilai Pelanggan terhadap Kepercayaan Pelanggan. Artinya semakin tinggi Nilai Pelanggan, semakin tinggi pula Kepercayaan Pelanggan.

6. Tidak Terdapat pengaruh yang signifikan antara Kepuasan Pelanggan terhadap Loyalitas Pelanggan. Artinya berapapun Nilai Kepuasan Pelanggan, tidak mempengaruhi tinggi rendahnya Nilai Loyalitas Pelanggan.

7. Terdapat pengaruh yang signifikan dan positif antara Nilai Pelanggan terhadap Loyalitas Pelanggan. Artinya semakin tinggi Nilai Pelanggan, semakin tinggi pula Loyalitas Pelanggan.

8. Terdapat pengaruh yang signifikan dan positif antara Kepercayaan Pelanggan terhadap Loyalitas Pelanggan. Artinya semakin tinggi Kepercayaan Pelanggan, semakin tinggi pula Loyalitas Pelanggan. 


\section{PEMBAHASAN}

\section{Pengaruh Kualitas Layanan terhadap Loyalitas Pelanggan Dimediasi Kepuasan Pelanggan.}

Pengujian hipotesis mediasi pada pengaruh Kualitas Layanan terhadap Loyalitas Pelanggan dimediasi Kepuasan Pelanggan secara lengkap disajikan pada Tabel dibawah ini, secara grafik disajikan sebagai berikut :

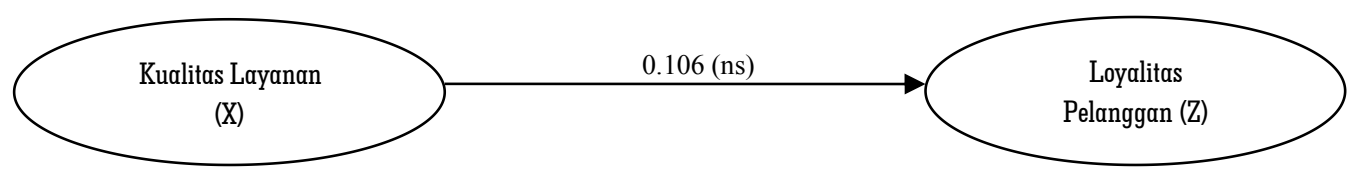

(a) Model tanpa melibatkan Variabel Mediasi

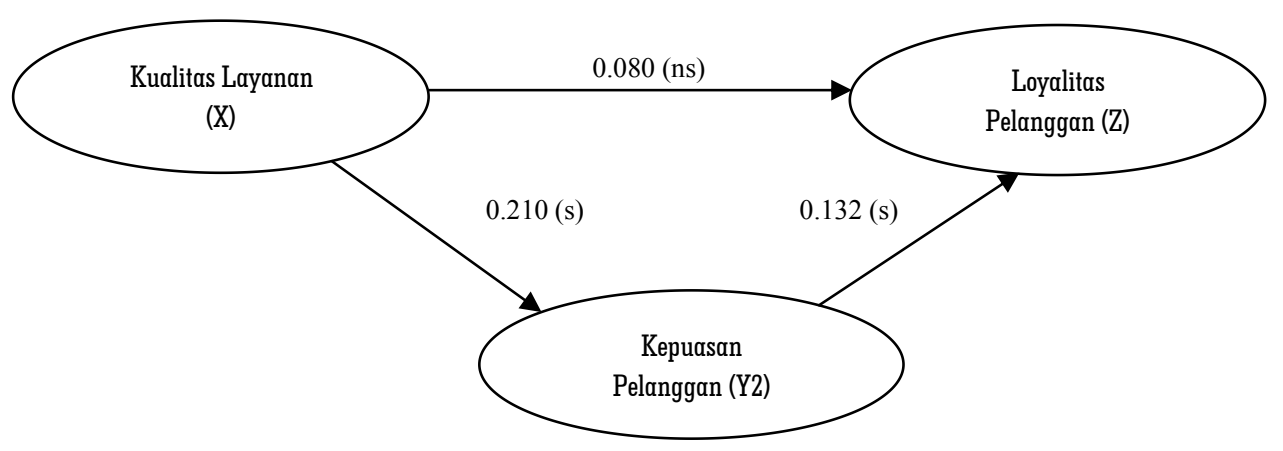

(b) Model dengan melibatkan Variabel Mediasi

Hasil penelitian ini mendukung hasil penelitian empirik yang menyimpulkan bahwa kepuasan pelanggan berpengaruh positif dan signifikan terhadap loyalitas pelanggan pada merek atau perusahaan (Jari, J, Jouni Juntunen dan Grand, 2006; Zahara, 2007; Denga, Lua, Weilb dan Zhanga, 2009; Trivellas, 2010; Frimpong, Nwankwo dan Dason, 2010; Kasim dan Abdullah, 2010). Semakin baik kepuasan yang dirasakan pelanggan atas kinerja barang/jasa, maka semakin loyal pelanggan b pada merek atau produk tertentu.

\section{Pengaruh Kualitas Layanan terhadap Loyalitas Pelanggan Dimediasi oleh Nilai Pelanggan.}

Pengujian hipotesis mediasi pada pengaruh Kualitas Layanan terhadap Loyalitas Pelanggan melalui Nilai Pelanggan, secara lengkap disajikan pada Tabel dibawah ini, secara grafik disajikan sebagai berikut :

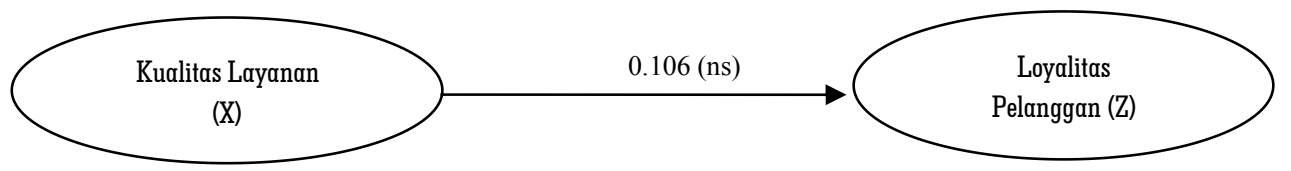

(a) Model tanpa melibatkan Variabel Mediasi

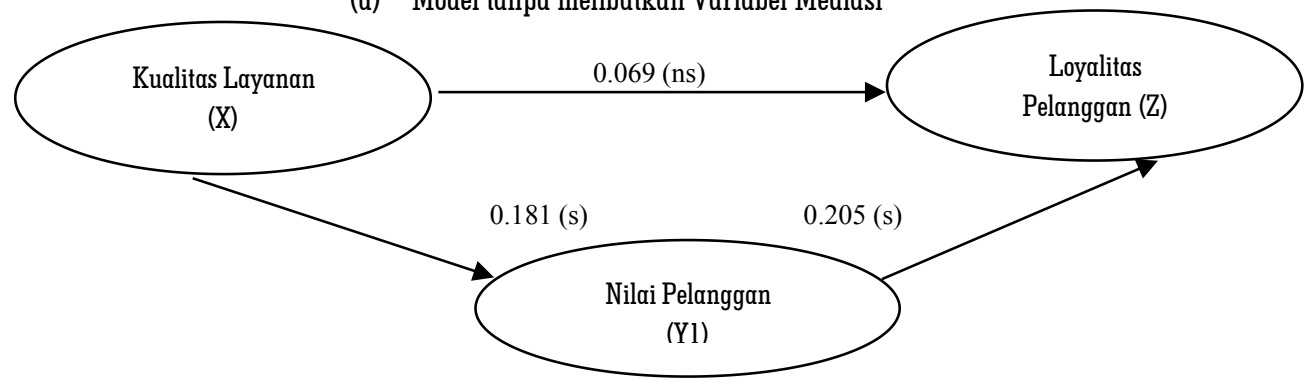

(b) Model dengan melibatkan Variabel Mediasi 
Hasil penelitian ini memperkuat hasil penelitian empirik yang menyimpulkan bahwa nilai pelanggan berpengaruh positif dan signifikan terhadap loyalitas pelanggan pada merek produk atau merek perusahaan (Sivadas dan Baker, 2000; Zahara, 2007; Trivellas, 2010). Artinya semakin tinggi nilai pelanggan yang diperoleh pelanggan dari perusahaan, maka semakin baik pula loyalitas pelanggan pada merek produk atau merek perusahaan.

Hasil penelitian ini membuktikan teori yang dikemukakan Brady dan Cronin (2002) bahwa Kualitas layanan berpengaruh terhadap peningkatan nilai yang diperoleh pelanggan. Chung Hao Chen (2009) menyatakan bahwa pelanggan yang merasa memperoleh layanan baik ditinjau dari kualitas interaksi, kualitas lingkungan fisik dan kualitas hasil sesuai atau melebihi harapan berarti pelanggan merasa telah memperoleh nilai sesuai atau melebihi harapannya.

\section{Pengaruh Kualitas Layanan terhadap Kepuasan Pelanggan Dimediasi oleh Nilai Pelanggan.}

Pengujian hipotesis mediasi pada pengaruh Kualitas Layanan terhadap Kepuasan Pelanggan melalui Nilai Pelanggan secara lengkap disajikan pada Tabel dibawah ini, secara grafik disajikan sebagai berikut :

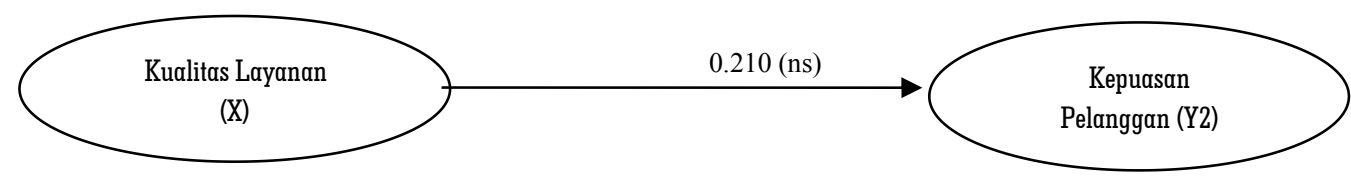

(a) Model tanpa melibatkan Variabel Mediasi

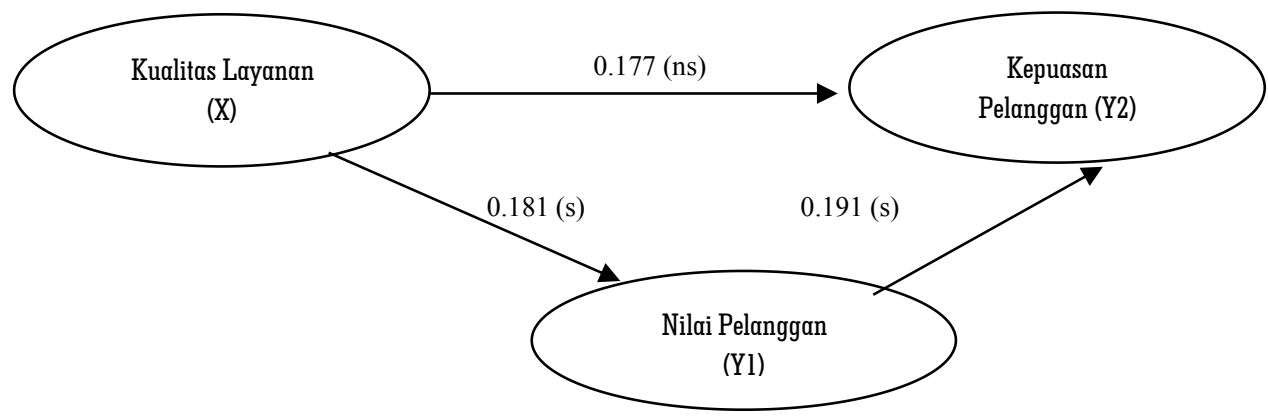

(b) Model dengan melibatkan Variabel Mediasi

Hasil penelitian tersebut sesuai sesuai dengan hasil beberapa penelitian terdahulu yang menyatakan bahwa kualitas layanan berpengaruh positif dan signifikan terhadap kepuasan pelanggan atas produk/jasa (Caruana, 2002; Cronin dan Taylor, 2002; Spreng, 2004; Lai, Griffin Babin, 2008; Santouridis dan Trivellas, 2010; Frimpong, Nwankwo dan Dason, 2010; Kassim dan Abdullah, 2010). Semakin baik kualitas layanan yang diperoleh pelanggan, maka semakin tinggi pula kepuasan yang dirasakan oleh pelanggan.

Sementara hasil peneliti lain mempercayai bahwa layanan yang berkualitas diperlukan untuk membangun dan mempertahankan nilai pelanggan dan loyalitas pelanggan.

Hasil penelitian ini memperkuat teori yang dikemukakan Brady dan Cronin (2002) bahwa Kualitas layanan berpengaruh terhadap peningkatan nilai yang diperoleh pelanggan. Chung Hao Chen (2009) menyatakan bahwa pelanggan yang merasa memperoleh layanan baik ditinjau dari kualitas interaksi, kualitas lingkungan fisik dan kualitas hasil sesuai atau melebihi harapan berarti pelanggan merasa telah memperoleh nilai sesuai atau melebihi harapannya. 


\section{Pengaruh antara Kepuasan Pelanggan terhadap Loyalitas Pelanggan Dimediasi oleh Kepercayaan Pelanggan.}

Pengujian hipotesis mediasi pada pengaruh Kepuasan Pelanggan terhadap Loyalitas Pelanggan melalui Kepercayaan Pelanggan secara lengkap disajikan pada Tabel dibawah ini, secara grafik disajikan sebagai berikut:

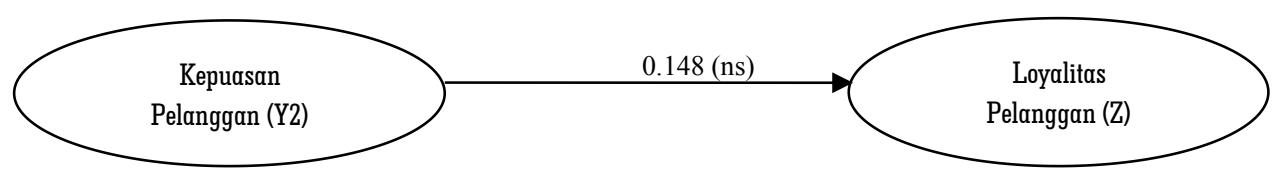

(a) Model tanpa melibatkan Variabel Mediasi

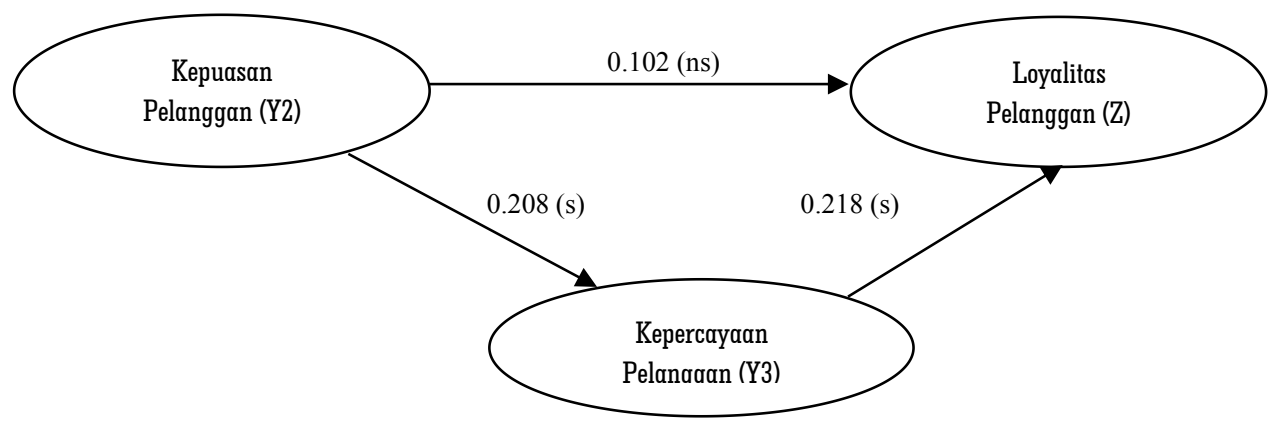

(b) Model dengan melibatkan Variabel Mediasi

Hasil penelitian ini memperkuat hasil penelitian empirik yang menyimpulkan bahwa Kepercayaan pelanggan berpengaruh positif dan signifikan terhadap loyalitas pelanggan (Kasim dan Abdullah, 2010). Artinya semakin tinggi kepuasan yang dirasakan pelanggan atas kinerja barang/jasa, maka semakin tinggi pula loyalitas pelanggan pada perusahaan.

\section{Pengaruh antara Nilai Pelanggan terhadap Loyalitas Pelanggan Dimediasi oleh Kepercayaan Pelanggan.}

Pengujian hipotesis mediasi pada pengaruh Nilai Pelanggan terhadap Loyalitas Pelanggan melalui Kepercayaan Pelanggan secara lengkap disajikan pada Tabel dibawah ini, secara grafik disajikan sebagai berikut:

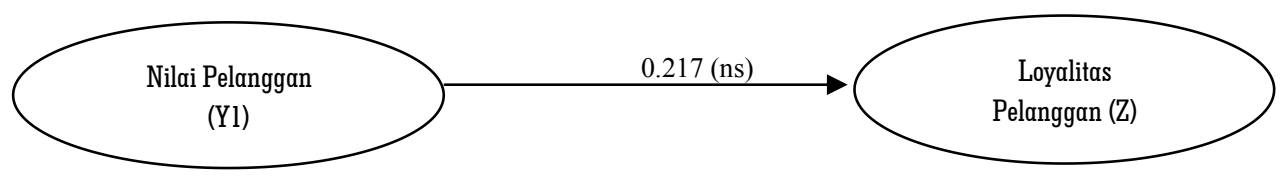

(a) Model tanpa melibatkan Variabel Mediasi

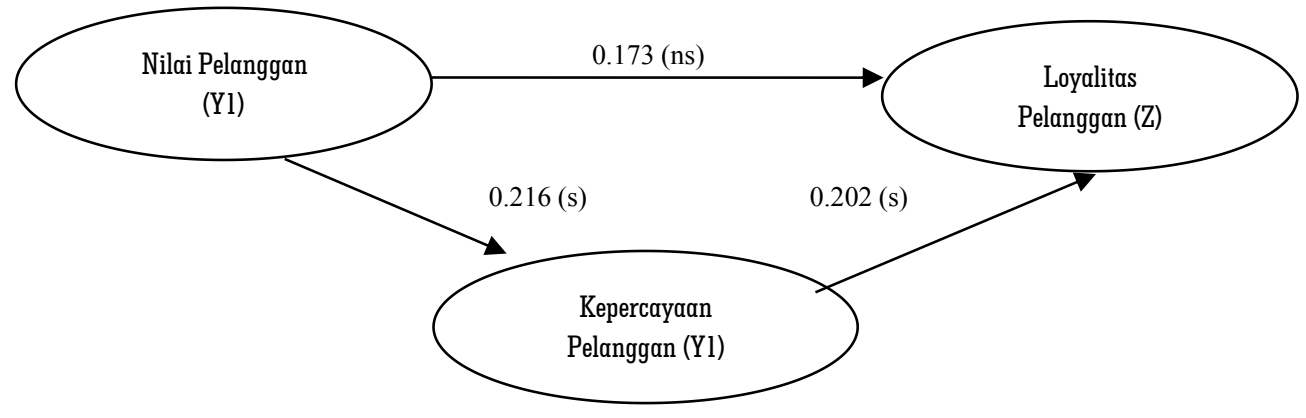

(b) Model dengan melibatkan Variabel Mediasi 
Hasil penelitian ini mendukung hasil penelitian empirik yang menyimpulkan bahwa kepercayaan pelanggan berpengaruh positif dan signifikan terhadap loyalitas pelanggan (Kasim dan Abdullah, 2010). Artinya Semakin baik kepuasan yang dirasakan pelanggan atas kinerja/jasa, maka semakin baik loyalitas pelanggan pada perusahaan. Hasil penelitian ini juga mendukung teori yang dikemukakan oleh Lai Griffin dan Babin (2008) menyatakan nilai pelanggan dilihat dari manfaat ekonomi dan sosial yang diterima dari perusahaan sebagai imbalan pengorbanan yang dikeluarkan, sehingga berdampak pada peningkatan loyalitas pelanggan. Lee dan Yoo (2009) menyatakan bahwa pelanggan yang menilai dan memperoleh nilai sesuai atau melebihi pengorbanan yang dikeluarkan menimbulkan perasaan loyal pada produk atau perusahaan.

Hal ini didukung dengan hasil penelitian empirik yang menyimpulkan bahwa nilai pelanggan berpengaruh positif dan signifikan terhadap loyalitas pelanggan pada merek produk atau perusahaan (Lai Griffin dan Babin, 2008; Lee dan Yo0, 2009; Trivellas, 2010).

\section{KESIMPULAN}

Berdasarkan hasil analisis data penelitian dan pembahasan, dapat ditarik beberapa kesimpulan sebagai berikut:

1. Kualitas layanan PDAM di Kota Kendari dapat meningkatkan loyalitas pelanggan melalui nilai pelanggan. Artinya apabila kualitas layanan yang dirasakan pelanggan baik, maka nilai atas pelayanan yang dirasakan pelanggan juga baik yang terwujud dalam bentuk kemudahan memperoleh pelayanan, penetapan tarif layanan dianggap wajar, dan menyampaikan keluhan pada PDAM dengan cara sopan.

2. Kualitas layanan PDAM di Kota Kendari dapat meningkatkan kepuasan pelanggan PDAM melalui nilai pelanggan. Apabila kualitas layanan yang dirasakan pelanggan baik, maka nilai yang diperoleh atas pelayanan yang diberikan PDAM juga baik (dalam hal ini bagaimana memperoleh kemudahan dalam pelayanan, penetapan tarif layanan yang wajar, adanya empati dan konsistensi pelayanan). Bila pelanggan mempersepsikan adanya nilai yang lebih baik, selanjutnya pelanggan merasa puas (berupa kepuasan atas produk air bersih, layanan dan manfaat).

3. Kepuasan pelanggan PDAM di Kota Kendari yang makin tinggi dapat meningkatkan loyalitas pelanggan PDAM melalui kepercayaan pelanggan. Apabila kepuasan yang dirasakan pelanggan baik, maka kepercayaan dalam bentuk percaya atas kehandalan, kualitas, kejujuran dan perhatian yang ditunjukkan karyawan dalam melayani pelanggan akan semakin kuat. Dengan demikian, pelanggan akan cenderung makin loyal untuk berperilaku positif berkaitan dengan PDAM.

4. Nilai pelanggan PDAM di Kota Kendari dapat meningkatkan loyalitas pelanggan PDAM melalui kepercayaan pelanggan. Apabila nilai layanan yang dirasakan pelanggan baik, maka kepercayaan atas pelayanan yang diberikan juga makin tinggi (dalam hal ini kepercayaan terwujud dalam bentuk kehandalan, kualitas, kejujuran dan perhatian yang ditunjukkan karyawan dalam melayani pelanggan). Dengan demikian, pelanggan akan menunjukkan loyalitasnya baik dalam ketepatan waktu membayar maupun tidak beralih menggunakan sumur bor.

5. Secara keseluruhan dapat disimpulkan bahwa di PDAM Kota Kendari, teori yang menyatakan pelanggan yang puas akan loyal tidak terbukti. Pelanggan yang puas hanya akan loyal bila kepuasan tersebut mampu meningkatkan kepercayaan. Selain kepercayaan, nilai pelanggan adalah penting untuk membangun loyalitas pelanggan. Dalam penelitian ini nilai pelanggan terbukti menjadi mediator paling penting yang meningkatkan pengaruh mutu layanan terhadap loyalitas pelanggan. 


\section{SARAN}

Berdasarkan hasil analisis data penelitian dan pembahasan, dapat disarankan beberapa hal, yaitu:

1. Walaupun secara deskriptif, baik dalam mutu layanan, kepuasan pelanggan maupun nilai pelanggan dinilai baik oleh responden, perlu diingat bahwa atribut layanan pelanggan yang diinginkan pelanggan bisa berubah setiap saat. Karena itu PDAM Kota Kendari perlu terus mengikuti kejelasan atribut yang dibutuhkan pelanggan secara periodik.

2. PDAM memerlukan pemikiran yang kreatif bagaimana meningkatkan kepuasan pasif menjadi kepuasan yang menimbulkan rasa sangat senang (delight) sehingga mendorong terciptanya perilaku loyal. Selain kepuasan, nilai pelanggan dan kepercayaan adalah kunci untuk membangun loyalitas. Dengan demikian PDAM perlu memperhatikan kewajaran tarif, konsistensi layanan, mempermudah penyampaian informasi serta secara berkesinambungan meningkatkan pemenuhan kebutuhan air dan kualitas air untuk rumah tangga khususnya dan seluruh pelanggan lainnya.

3. Direksi PDAM sebaiknya memperhatikan pelanggan untuk mendapatkan solusi untuk mengurangi jumlah pelanggan yang menunggak setiap tahun yang semakin meningkat sebesar 4.866 (27.24 \%) pelanggan dari jumlah pelanggan sebesar 18.342 pada tahun 2010 . 


\section{DAFTAR PUSTAKA}

Aftar, 2010. Service Loyality. The Effect Service Quality and The Mediation Role of Customer Setisfaction. Journal of Management, Vol. 36.

Brady, Michael, K., and J. Joseph, C, 2001. Some Though on conceptuallizing perceived service quality. A hierarchical approach. Journal of Marketing Vol. 65, 34-49.

Caruana, A. 2002. Service Loyality The Effect of Service Quality and The Mediating Role of Costumer Satisfaction, Euro Of Marketing Vol. 36 No. 7/8, pp. $811-828$.

Cheng, T.C.E., Lai, L, C.F, and Yeung, A.C.L. 2008. The Driving Forces of Customer Loyalty. A Study of Internet Service Providers in Hongkong, International Journal of E-Bussiness Research, Vol. 4, No. 4, pp. $26-42$.

Cronin, J.J, and Steven, A.T. 1994. Servperf Versus Servqual : Reconciling Performance-Based and ParceptionsMinus-Expctations Measurement of Service Quality. Journal of Marketing 58 (January) : 125 - 131.

Chung-Hao Chen, 2009. Development of A Model to Measure Customer Satisfaction with International Tourist Hotel in Taiwan. A Dissertation in Hospitality Administration Texas Tech University.

Denga, Z., Yaobin, L., Kwok, K.W., and Jinlong, Z. 2009. Understanding Customer Satisfaction and Loyality : An Empirical Study of Mobile Instant Massages in China. Journal of Management, Vol. 30.

Frimpong, N., and Dason. 2010. Measuring Service Quality and Patient Satisfaction with Access to Publik and Private Healthcare Delivery, Journal of Management, Vol. 23.

Jari, J., Jouni, J., and Grant. 2006. Service Quality and its Correlation to Satisfaction and Loyalty of Outsourcing Logistic, Journal of Management. Vol. 30.

Kasim, N., and Nor, A.A. 2010. The Effect of Perceived Service Quality Dimensions on Customer Satisfaction, Trust, and Loyalty in e-commerce Setting, A. Cross Cultural Analysis, Journal of Management Vol. 22.

Kuncoro, M. 2003. Metode riset untuk Bisnis dan Ekonomi. Jakarta : Erlangga.

Lai Fujan, M.G, and Berry, J.B. 2008. How Quality, Value, Image, and Satisfaction Create Loyality at Chiness Telecommunication, Journal of Management.

Trivellas, S. 2010. Investigation Impact of Service Quality and Customer Satisfaction on Customer Loyality in Mobile Telephone in Greece. Journal of Management, Vol. 22.

Zahara, Z. 2007. Peran Kualitas Layanan terhadap Kepuasan, Kepercayaan, Komitmen, dan Loyalitas Nasabah dalam Hubungan Kemitraan, Disertasi, Program Pascasarjana, Fakultas Ekonomi Universitas Brawijaya, Malang. 